Original article

DOI: 10.19027/jai.19.2.199-206

\title{
The addition of calcium oxide with different doses in the recirculation system to improve the abalone Haliotis squamata seed production
}

\section{Penambahan kalsium oksida dengan dosis yang berbeda pada sistem resirkulasi untuk meningkatkan produksi benih abalon Haliotis squamata}

\author{
Eddy Supriyono $^{1 *}$, Debora Victoria Liubana ${ }^{1}$, Tatag Budiardi ${ }^{1}$, \\ Irzal Effendi ${ }^{1}$ \\ 'Department of Aquaculture, Faculty of Fisheries and Marine Science, IPB University, \\ Bogor, West Java, Indonesia \\ *Cooresponding author : eddysupriyonoipb@gmail.com
}

(Received March 12, 2018; Accepted June 29, 2020)

\begin{abstract}
Information about abalone growth is necessary to overcome the abalone culture sustainability. Water quality parameters are aspects that need to be reviewed, one of which is the calcium level in the water. The aim of this study was to determine the optimal calcium dose in recirculation system for abalone Haliotis squamata growth. The study was conducted with an experimental method with four treatments (calcium oxide with doses of 0,15 , $30,45 \mathrm{mg} / \mathrm{L}$ ) and three times replications. Abalone with $2.3 \mathrm{~g}$ body weight, $2.3 \mathrm{~cm}$ shell length, and $1.2 \mathrm{~cm}$ shell width was reared for 60 days in recirculation system and fed with Gracilaria verrucosa. The results showed that the best abalone treatment medium with the addition of calcium oxide to increase the abalone seed production was $15 \mathrm{mg} / \mathrm{L} \mathrm{CaO}$ with $100 \%$ survival rate, $31.57 \pm 2.82 \%$ feed efficiency, and $0.56 \pm 0.06 \% /$ day specific growth rate.
\end{abstract}

Keywords: Abalone, calcium, organ composition, production, recirculation

\begin{abstract}
ABSTRAK
Informasi tentang pertumbuhan abalon diperlukan untuk mengatasi keberlanjutan budidaya abalon. Parameter kualitas air merupakan aspek yang perlu ditinjau. Kadar kalsium dalam air menjadi salah satu aspek yang dapat ditinjau.Tujuan dari penelitian ini adalah menentukan dosis kalsium optimal melalui sistem resirkulasi untuk pertumbuhan abalon Haliotis squamata. Penelitian ini dilakukan dengan metode eksperimental dengan empat perlakuan 3 ulangan penambahan $\mathrm{CaO}$ dengan dosis 0,15 , 30, dan $45 \mathrm{mg} / \mathrm{L}$. Secara singkat, abalon dengan bobot badan 2,3 g, panjang cangkang $2,3 \mathrm{~cm}$ dan lebar cangkang $1,2 \mathrm{~cm}$ dipelihara selama 60 hari dengan sistem resirkulasi dan diberi makan dengan Gracilaria verrucosa. Hasil penelitian menunjukkan bahwa media perlakuan abalon dengan penambahan kalsium oksida terbaik untuk meningkatkan produksi abalon adalah $\mathrm{CaO} 15 \mathrm{mg} / \mathrm{L}$ dengan tingkat kelangsungan hidup $100 \%$, efisiensi pakan $31,57 \pm 2,82 \%$, dan laju pertumbuhan spesifik harian $0.56 \pm 0.06 \% /$ hari.
\end{abstract}

Kata kunci: Abalon, kalsium, komposisi organ, produksi, resirkulasi 


\section{INTRODUCTION}

Abalone Haliotis squamata is a herbivorous marine gastropod. Abalone is one of great demanded marine commodities because of its high nutrient contents, distinct taste, and health benefits obtained (Sarifin et al., 2011; Nurfajrie et al., 2014). High market demand of abalone from 134,000 tons in 2015 increased by 150,000 tons in 2016 (FAO, 2017) with the selling price reaches $1,000,000 / \mathrm{kg}$. The abalone supply from culture production has not been maximized, causing an increased natural exploitation, resulting a decreased total population of abalone seeds in the original habitat. The improved abalone seed production through culture can be performed by a flow-through system (Nur, 2020). This system can improve the cultured organism survival rate and growth. Nevertheless, this system has disadvantages, namely, requiring a large amount of water, difficulties in water control treatment, and other biological impacts (Snow et al., 2020). Therefore, a more efficient alternative technology is necessary for obtaining a high seed production that can fulfill the market demand.

Recirculation system is a system that reutilizes water by continuously turning the water around through a filter or into a tank (Fauzzia et al., 2013; Thesiana \& Pamungkas, 2015). This system is commonly applied in a region far from abundant water source, therefore preserving the water and land use. Recirculation system has an effect on the culture environment claimed to more environmentally friendly due to maintaining the water waste from the culture tank and returning it to the tank with the quality closed to its previous. The waste management in recirculation system is performed by applying the mechanical and biological filters (Aji, 2012). Irvandi (2017) conducted a study of abalone stocking density in a filtrated recirculation system at $1.5 \mathrm{~g} / \mathrm{ind}$. size with 100,200 , and $300 \mathrm{ind} / \mathrm{m}^{2}$. This study resulted an insignificant difference among different stocking densities on length growth and shell width. Decreased several production parameters were suspected due to the unoptimized rearing media quality. Moreover, a certain compound addition is thought to help improve the length growth and shell width.

Abalone requires some minerals for the metabolic process, membrane permeability, and shell formation process as the biggest part of the abalone body. Calcium is a mineral ion that plays a major role in bone and teeth formation, body skeleton rigidity maintenance, blood thickening, skeletal, heart, other tissue muscle regulations, muscle relaxation and contraction, osmotic balance maintenance, and shell formation (Zainuddin, 2010; Damayanti et al., 2018). Calcium in calcium carbonate is a biomineral that is mostly found in mollusk and crustacean body (Džakula et al., 2013; Purba et al., 2015). Based on the results of Rahayu et al. (2015), the crushed clam shell produced as a powder had a calcium content of 92\%. Abdullah et al. (2010) also added that calcium was needed in large amount to form a shell, therefore the calcium addition from the outside should be considered. The shell formation process will be more effective in culture media has a sufficient $\mathrm{Ca}^{2+}$ ion as capable of helping the homeostatic process (Hastuti et al., 2012). The abalone culture technology development related to the calcium content in culture media for seed production improvement needs to be performed. Therefore, the aim of this study was to determine the best dose of calcium oxide $(\mathrm{CaO})$ addition in the filtrated recirculation system to improve the abalone seed production.

\section{MATERIALS AND METHODS}

\section{Tank preparation}

This study used aquaria with $80 \mathrm{~cm} \times 30 \mathrm{~cm} \times 40$ $\mathrm{cm}$, which were initially cleaned from wastes. Aquaria were disinfected using a $30 \mathrm{~g} / \mathrm{L}$ calcium hypochlorite and rinsed with a clean water, then stood for 24 hours. Aquaria were filled with marine water at $30 \mathrm{~g} / \mathrm{L}$ salinity as much as $15 \mathrm{~L}$. In this step, a recirculation system was made for each treatment. Each aquarium was placed three shelters from polyvinyl chloride (PVC) pipes at 10 $\mathrm{cm}$ diameter with both hole sides were enclosed with gauze. A water pump was set for each recirculation system. Each rearing tank was set two aerations for oxygen stabilizing maintenance.

\section{Experimental media preparation}

The $\mathrm{CaO}$ lime (calcium oxide) was bought in a powder form and kept in a dry place. Before being used for treatment, the $\mathrm{CaO}$ lime was initially mashed before measured based on treatment doses, namely the addition of $\mathrm{CaO}$ with $15 \mathrm{mg} / \mathrm{L}$, $30 \mathrm{mg} / \mathrm{L}$, and $45 \mathrm{mg} / \mathrm{L}$. The measured $\mathrm{CaO}$ limes based on the treatments were initially dissolved in $240 \mathrm{~mL}$ water referred to the measuring glass size used, then poured in media based on the treatment doses. 


\section{Experimental fish preparation}

The experimental fish used were 10 abalone Haliotis squamata for each replication. The abalones were obtained from Gondol Main Center for Marine Culture Research and Development, Bali. The initial weight of abalone was $2.3 \mathrm{~g}$ with $2.3 \mathrm{~cm}$ shell length and $1.2 \mathrm{~cm}$ shell width.

\section{Experimental feed}

The feed used was seaweed Gracilaria verrucosa obtained from Karawang. The seaweed was cleaned using a freshwater. The seaweed was then moved into the prepared and aerated aquaria. The seaweed remains were placed in a container to keep the feed in a wet condition. The feed was given ad libitum with twice a day frequency (Kuncoro et al., 2013).

\section{Sampling}

Rearing was performed for 60 days. Samples were taken as much as 12 abalones once in 15 days from each treatment to measure their shell length, shell width, and weight. The dead abalones were measured each day and accumulated once in 15 days.

\section{Parameters}

Survival rate

The number of abalones was calculated at the initial study period. At the final rearing, the number of surviving abalones were calculated and divided by the number of abalones at the initial rearing. The calculation results of initial and final number of abalones were calculated using the formula of Effendie (1997):

$$
\mathrm{SR}(\%)=\frac{\mathrm{N}_{\mathrm{t}}}{\mathrm{N}_{0}} \times 100
$$

Note :

$\mathrm{SR}=$ Survival rate $(\%)$

$\mathrm{Nt} \quad=$ The final number of experimental animals

No $\quad=$ The initial number of experimental animals

\section{Feed efficiency}

To identify how much abalone consumed the feed and digested it, abalone was measured and noted at the initial and final study. The number of dead abalones during the study were measured and noted. The feed weight given from initial to final study was measured and noted. The calculation of feed efficiency was based on Tacon (1993):

$$
E P=\frac{\left(W_{t}+D\right)}{F}-W_{0} \times 100
$$

Note :

$\mathrm{EP} \quad=$ Feed efficiency $(\%)$

$\mathrm{Wt}=$ Experimental animal biomass at the final study $(\mathrm{g})$

D $=$ Dead experimental animal weight during the study $(\mathrm{g})$

Wo = Experimental animal biomass at the initial study $(\mathrm{g})$

$\mathrm{F} \quad=$ Amount of feed given in wet weight (g)

Specific growth rate

The specific growth rate (SGR) can be defined as the fish weight change in weight, size, or volume along with the time change. The specific growth rate (SGR) was calculated based on Huisman (1987) formula:

$$
\mathrm{SGR}=\frac{\left(\ln \mathrm{W}_{\mathrm{t}}-\ln \mathrm{W}_{0}\right)}{\mathrm{t}} \times 100
$$

Note:

SGR : Specific growth rate (\%/day)

$\mathrm{Wt}$ : Average abalone weight at the final rearing $(\mathrm{g} / \mathrm{ind})$

Wo : Average abalone weight at the initial rearing $(\mathrm{g} / \mathrm{ind})$

t $\quad$ : Rearing period (day)

Length growth rate

The length growth rate (LPP) is the length change from the initial to the final study. The length growth rate was calculated based on the formula (Allen et al., 2006):

$$
\mathrm{LPP}=\frac{\left(\mathrm{SL}_{\mathrm{t}}-\mathrm{SL}_{0}\right)}{\mathrm{t}} \times 10000
$$

$$
\begin{array}{ll}
\text { Note : } & \\
\text { LPP } & =\text { Shell length growth rate }(\mu \mathrm{m} / \text { day }) \\
\text { SLt } & =\text { Final shell length }(\mathrm{cm}) \\
\text { SL0 } & =\text { Initial shell length }(\mathrm{cm}) \\
\mathrm{t} & =\text { Period (day) }
\end{array}
$$

\section{Data analysis}

The survival rate, specific growth rate, and length growth rate were processed using an analysis of variance at $95 \%$ degree of confidence level. When there was a significant difference, data were continuously processed with a Tukey test. The data analysis was performed using Microsoft Excel 2010 and SPSS 21 software. 


\section{RESULTS AND DISCUSSION}

\section{Result}

Survival rate

The abalone survival rate in a treatment without $\mathrm{CaO}$ addition was $63.33 \%$. The survival rate percentage in $15 \mathrm{mg} / \mathrm{L} \mathrm{CaO}$ treatment reached $100 \%$. However, this percentage decreased gradually along with the addition of $\mathrm{CaO}$, namely, $80.00 \%$ in $30 \mathrm{mg} / \mathrm{L}$ treatment and $73.33 \%$ in 45 $\mathrm{mg} / \mathrm{L}$ treatment.

\section{Feed efficiency}

Based on the calculation results (Figure 2), the feed efficiency of abalone showed a significant difference $(\mathrm{P}<0.05)$ result among treatments. The treatment dose of $15 \mathrm{mg} / \mathrm{L}$ calcium oxide $(\mathrm{CaO})$ obtained the highest feed efficiency, namely, $31.57 \pm 2.82 \%$ and control treatment $(0 \mathrm{mg} / \mathrm{L})$ obtained the lowest feed efficiency, namely, 23.18 $\pm 1.37 \%$.

\section{Specific growth rate (SGR)}

The different lime dose addition was significantly different in the specific growth rate of abalone $(\mathrm{P}<0.05)$. The highest specific growth rate value was obtained from $15 \mathrm{mg} / \mathrm{L}$ treatment, namely, $0.56 \pm 0.06 \%$, while the lowest was obtained from $45 \mathrm{mg} / \mathrm{L}$ treatment, namely, $0.39 \pm$ $0.01 \%$ (Figure 3 ).

\section{Length growth rate}

The different lime dose addition was significantly different on the shell length growth $(\mathrm{P}<0.05)$. Based on the shell length growth calculation (Figure 4), the highest was obtained from B treatment with $151.89 \pm 11.00 \mu \mathrm{m}$, while the lowest was obtained from $\mathrm{D}$ treatment with $111.75 \pm 2.82 \mu \mathrm{m}$.

\section{Discussion}

The survival rate is one of the main parameters that indicates the success of an aquaculture

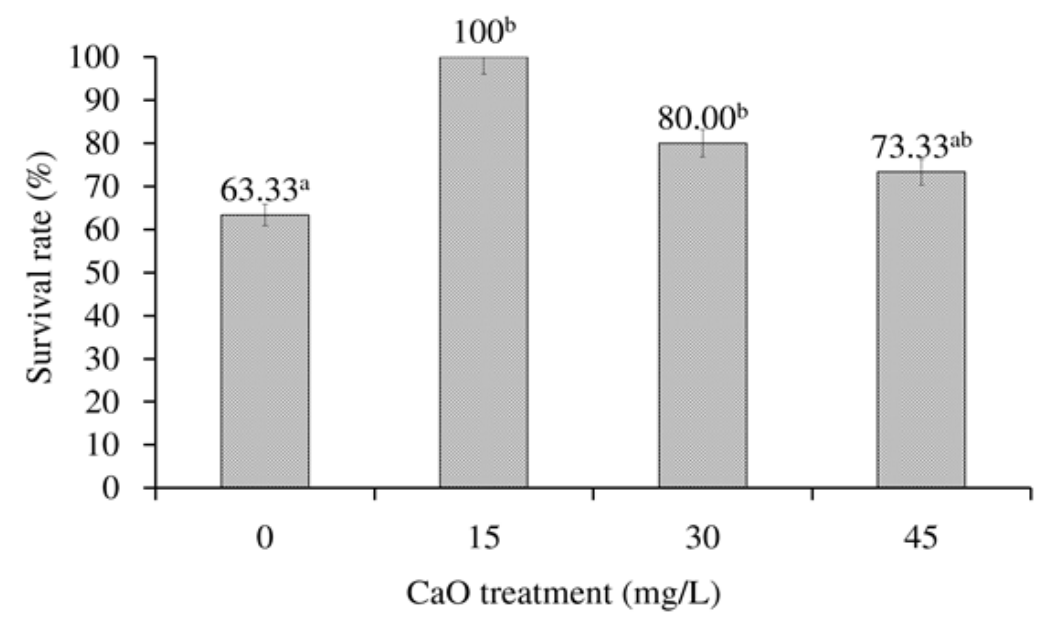

Figure 1. The survival rate of abalone. Different letters on the bars show a significant difference at $5 \%$ degree level (Tukey test).

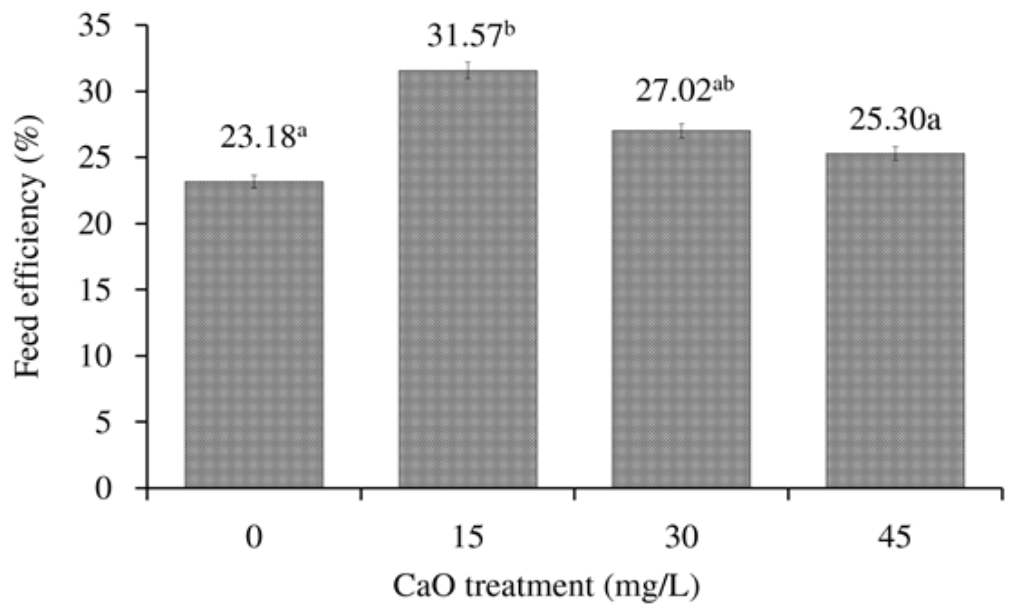

Figure 2. The feed efficiency of abalone. Different letters on the bars show a significant difference at $5 \%$ degree level (Tukey test). 
commodity maintenance (Rachimi et al., 2016). The biotic and abiotic factors directly influence the growth and survival rate. As shown in Figure 1 , the survival rate of abalone was significantly different among treatments $(\mathrm{P}<0.05)$. The 15 $\mathrm{mg} / \mathrm{L} \mathrm{CaO}$ treatment produced the survival rate of $100 \%$ at the final rearing. This study supported the statement of Kelabora (2014) that the survival rate increased after the optimal calcium addition in the media and decreased after high calcium addition in the media. This condition indicates that the optimal culture media will support the abalone life.

The low survival rate level in $0 \mathrm{mg} / \mathrm{L}$ was thought due to lack of $\mathrm{Ca}^{2+}$ ion and water quality reduction (water $\mathrm{pH}$ ) that caused abalone stress (Karim et al., 2017). The stressed abalone is characterized as strongly attached to the substrate when being touched, inactive movement, or moving to the pond side enclosed to the water surface (Lockman et al., 2017). Abalone is very sensitive against friction, therefore necessary to be carefully handled (Rejeki et al., 2014; Hayati et al., 2018).
Feed efficiency (FE) is the ratio of body weight increment produced and the feed consumed. Figure 2 shows that the highest FE value was obtained from $15 \mathrm{mg} / \mathrm{L} \mathrm{CaO}$ dose treatment with $31.57 \pm 2.82 \%$. High FE indicates that the energy utilization obtained from feed was more used for growth and survival than for osmoregulation or daily maintenance. This surely implicates on the increased specific growth rate and shell length. Meanwhile, lower feed efficiency in 0 $\mathrm{mg} / \mathrm{L}$ treatment with $23.18 \%$ was thought due to the abalone seeds were in the hyperosmotic condition, which utilized more energy to sustain the ion balance in the body and its environment. Thereby, the feed utilization became less efficient. Feed containing protein, lipid, and minerals, especially calcium, plays a role in supporting the abalone growth (Susanto et al., 2010). Mineral contained in feed is used in the shell biosynthesis process, while mineral in the red blood cells are used for sustaining the osmotic pressure, besides becoming enzyme components (Affandi et al., 2011).

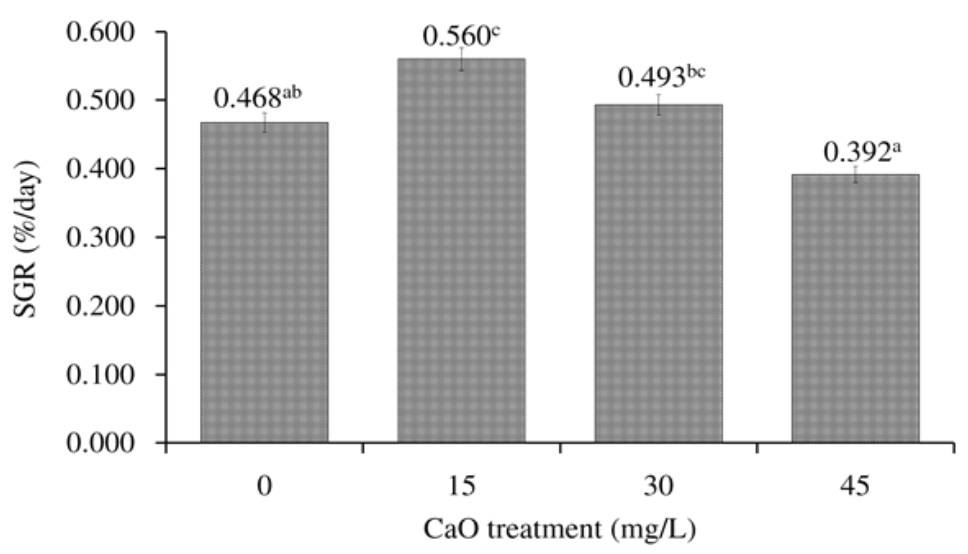

Figure 3. The specific growth rate (SGR) of abalone. Different letters on the bars show a significant difference at $5 \%$ degree level (Tukey test).

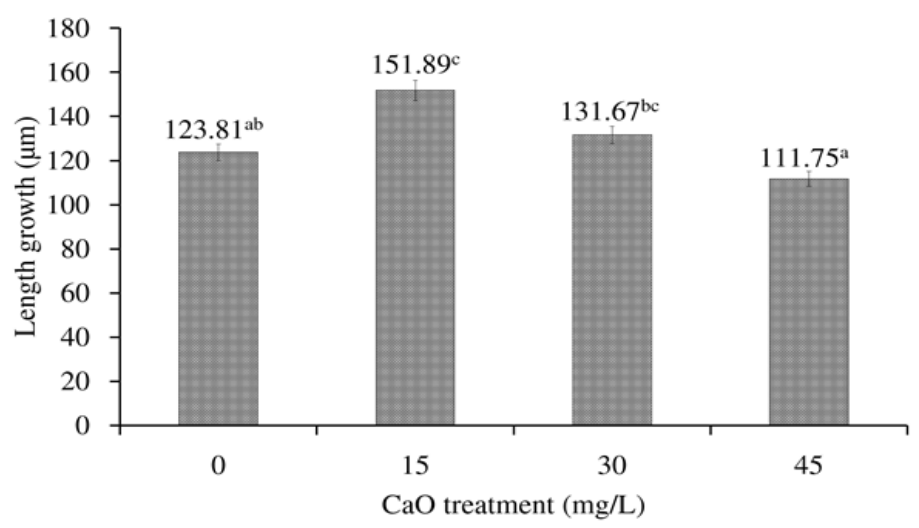

Figure 4. The length growth value of abalone shell. Different letters on the bars show a significant difference at 5 $\%$ degree level (Tukey test). 
Growth is an important component in the productivity. Growth will perform well whenever the fish body approaches the isoosmotic condition (Diansyah et al., 2014). This condition causes the physiological process can perform well, therefore the available energy used for daily maintenance remains low and energy allocation for growth is maximized. The specific growth rate of abalone during rearing showed that the $15 \mathrm{mg} / \mathrm{L} \mathrm{CaO}$ treatment had the highest growth compared to other treatments with $0.56 \pm 0.06 \% /$ day. High growth rate indicates that the osmotic pressure in rearing media and abalone body approach the isoosmotic condition. The ion concentration is relatively balanced; therefore abalone does not need to allocate an extra energy for balancing the osmotic pressure inside and outside of the body. Thereby, abalone can utilize the feed well for its growth. The study results of Nurussalam et al. (2017) showed that crabs reared in media with calcium and magnesium content more than $30 \mathrm{mg} / \mathrm{L}$ for once in 15 days could cause stress. When there is a high osmotic pressure, then the energy allocation for osmoregulation will be greater. This condition can end up to a minimum energy utilized for growth (Pamungkas, 2012; Yuliani et al., 2018).

The clamp growth is divided into two parts, namely, flesh growth and shell growth (Runtu et al., 2016). The length growth rate of abalone shell in $\mathrm{CaO}$ addition treatments $(15,30$, and 45 $\mathrm{mg} / \mathrm{L}$ ) during the study ranged between 0.01$0.02 \mathrm{~cm} /$ day. The low growth value in $45 \mathrm{mg} / \mathrm{L}$ $\mathrm{CaO}$ treatment was suspected due to high $\mathrm{Ca}^{2+}$ ion availability in the water that was unable to be absorbed well by abalone. This condition may occur due to calcium in the water was bound to other matters. Calcium in marine water can bind to $\mathrm{CO}_{2}$ for forming $\mathrm{CaCO}_{3}$ (Bogart, 2016). The shell length growth is correlated to the weight growth. This condition is characterized as a symmetric shell and flesh growth of abalone. The value of abalone shell length growth in $15 \mathrm{mg} / \mathrm{L}$ $\mathrm{CaO}$ treatment $(151.89 \pm 11.00 \mu \mathrm{m} /$ day $)$ showed a better growth and significantly different from 45 $\mathrm{mg} / \mathrm{L} \mathrm{CaO}$ treatment $(111.75 \pm 2.82 \mu \mathrm{m})$.

\section{CONCLUSION}

The rearing media with the calcium oxide addition of $15 \mathrm{mg} / \mathrm{L}$ was the best treatment to significantly improve abalone Haliotis squamata production $(\mathrm{P}<0.05)$.

\section{REFERENCES}

Abdullah A, Nurjanah, Wardhani YK. 2010. Physical and chemical characteristic of local mussel shell flour Pilsbryoconcha exilis. Jurnal Pengolahan Hasil Perikanan Indonesia 13: 48-57.

Affandi R, Kelabora DM, Setyanto DD. 2011. Pengaruh penambahan kalsium pada media budidaya terhadap beban osmotik dan kaitannya dengan pertumbuhan kijing taiwan Anodonta woodiana LEA. Omni Akuatika 10: $1-6$.

Aji LP. 2012. Alternative practice from coastal pond to recirculation aquaculture system. Journal of Coastal Development 15: 125-132.

Allen VJ, Marsdem ID, Ragg NLC, Gieseq S. 2006. The effect of teactile stimulant on feeding, growth, behavior and meat quality of cultured black food abalone, Haliotis iris. Aquaculture 257: 294-308.

Bogart SJ, Samuel W, Dylan S, Cindy M, Greg GP. 2016. Rapid changes in water hardness and alkalinity: Calcite formation is lethal to Daphnia magna. Science of The Total Environment 559: 182-191.

Damayanti D, Yusup DS, Rusdi I. 2018. the effect of feeding some macro algae (Ulva sp., Gracilaria sp., Halymenia sp.) on the growth of Haliotis squamata abalone. Jurnal Metamorfosa 5: 189-197.

Diansyah S, Budiardi T, Sudrajat AO. 2014. Growth performance of 3-g Anguilla bicolor bicolor at different density. Jurnal Akuakultur Indonesia 13: 46-53.

Džakula BN, Reggi M, Falini G,Weber I, Brečević L, Kralja D. 2013. The influence of a protein fragment extracted from abalone shell green layer on the precipitation of calcium carbonate polymorphs in aqueous media. Croatia Chemica Acta 86: 39-47.

Effendie I. 1997. Biologi Perikanan Bogor (ID). Yayasan Pustaka Utama.

[FAO] Food and Agriculture Organization. 2017. Abalone production continues to grow, coupled with continuing demand, prices high and stable. FAO 33 Globefish.

Fauzzia M, Izza R, Nyoman W. 2013.Penyisihan amoniak dan kekeruhan pada sistem resirkulasi budidaya kepiting dengan teknologi membran biolfiter. JurnalTeknologi Kimia dan Industri II2: 155-161. 
Hastuti YP, Djokosetiyanto D, Permatasari I. 2012. Additional lime of $\mathrm{CaO}$ in rearing medium with salinity for growing of catfish Pangasius hypopthalmus. Jurnal Akuakultur Indonesia 11: 168-178.

Hayati H, Dirgayusa IGNP, Puspitha NLPT. 2018. Laju pertumbuhan kerang abalon Haliotis squamata melalui budidaya IMTA (integrated multi trophic aquaculture) di Pantai Geger, Nusa Dua, Kabupaten Badung, Provinsi Bali. Journal of Marine and Aquatic Sciences 4: 253-262.

Huisman EA. 1987. The principles of fish culture production. Department of fish culture and fisheries. Netherland (NL). Wageningen University.

Irvandi A.2017.Production Performance of Abalone Haliotis squamata in Recirculating System with Stocking Densities of 100, 200, and $300 \mathrm{ind} / \mathrm{m}$. [Skripsi]. Bogor (ID): Institut Pertanian Bogor.

Karim A, Rahman A, Effendy IJ. 2017. Study on growth and survival abalone juvenile Haliotis asinina fed microalgae and macroalgae cultured under IMTA (intergrated multitropihc aquaculture) system. Media Akuatika 2: 400-408.

Kelabora DM. 2014. Effisiensi pemanfaatan kalsium pada media budidaya untuk pertumbuhan kijing taiwan Anodonta woodiana, LEA. Berkala Perikanan Terubuk 42: 1-8.

Kuncoro A, Surdayono A, Sujangka A, Setyabudi H, Suminto. 2013. Effect of addition artificial diets containing different protein sources on feed efficiency, growth rate and survival rate of juvenile hybrid abalone. Journal of Aquaculture Management and Technology 2: $56-63$.

Lockman NA, Manan A, Arie M, Prayogo. 2017. Separating techniques shellfish abalone Haliotis squamata at the Center for Research and Development of Marine Aquaculture Gondol-Bali. Journal of Aquaculture and Fish Health 7: 78-83.

Pamungkas P. 2012. Aktivitas osmoregulasi, respons pertumbuhan, dan energetic cost pada ikan yang dipelihara dalam lingkungan bersalinitas. Media Akuakultur 7: 44-51.

Purba PD, Amri A, Zultiniar, Yelmida. 2015. Sintesa precipitated calcium carbonate (PCC) dari cangkang kerang darah Anadara granosa dengan variasi suhu kalsinasi dan variasi rasio $\mathrm{CaO} / \mathrm{HNO}_{3}$. Jurmal Online Mahasiswa 5: 1-7.

Nur KU. 2020. Abalone aquaculture in Asia: its technology and aquaculture management. Media Akuatika : Jurnal Ilmiah Jurusan Budidaya Perairan 5: 95-106.

Nurfajrie, Suminto, Rejeki S. 2014. The utilization of different types of macroalgae for growth abalone Haliotis squamata in aquaculture enlargement. Journal of Aquaculture Management and Technology 3: 142-150.

Nurussalam W, Nirmala K, Supriyono E, Hastuti YP. 2017. The frequency of calcium and magnesium differences in recirculation systems for increasing production of mud crab Scylla serrata seed. Jurnal Akuakultur Indonesia16: 144-153.

Rejeki S, Humaidi H, Ariyati RW. 2014. Pembesaran siput abalon Haliotis squamata dalam keramba tancap di area pasang surut dengan padat tebar yang berbeda. Journal of Aquaculture Management and Technology 3: 214-221.

Sarifin, Bayu P, Hery S, Gagan G, Arif S, Ade Y. 2011. Petunjuk Teknis Budidaya Abalon Haliotis spp. Balai Budidaya Laut Lombok, Direktorat Jenderal Perikanan Budidaya, Kementrian Kelautan dan Perikanan.

Rachimi, Raharjo EI, Putra DA. 2016. The influence of calcium oxide $(\mathrm{CaO})$ addition on salinity aquaculture Media to the crayfish Cherax quadricarinatus growth and survival rate. Jurnal Ruaya 4: 2541-3155.

Rahayu R, Leksono T, Desmelati. 2015. Analisis kandungan mineral pada tepung cangkang kerang air tawar Pilsbryoconcha exilis berdasarkan ukuran cangkang yang berbeda. Jurnal Online Mahasiswa 2: 1-10.

Runtu RYA, Lumenta C, Sampekalo J. 2016. Utilization of shell powder of Taiwanese mussel for the growth of Taiwanese mussel Anondonta woodiana. Budidaya Perairan 4: 22-30.

Snow A, Anderson B, Wootton B. 2012. Flowthrough land-based aquaculture wastewater and its treatment in subsurface flow constructed wetlands. Environmental Reviews 20: 54-69.

Susanto B, Rusdi I, Ismi S, Rahmawati R. 2010. Rearing of abalone Haliotis squamata F-1 generation juvenile through different kinds of feed. Jurnal Riset Akuakultur 5: 199-209. 
Tacon AGJ. 1993. Feed ingredient for warmwater fish. Fish meal and other processed feedstuffs. AO Fisheries Circular, Rome, 64 pp.

Thesiana L, Pamungkas A. 2015. Performance test of recirculating aquaculture system (RAS) technology to water quality condition in spiny lobster Panulirus homarus nursery. Jurnal Kelautan Nasional 10: 65-74.

Yuliani TA, Anggoro S, Solichin A. 2018. The influence of difference salinity on osmotic response, ionic regulation and growth of sidat Anguilla sp. elver phase during acclimation and cultivation period. Journal of Maquares 7: 333-341.

Zainuddin. 2010. The effect of calcium and phosphorous on growth, feed efficiency, mineral content and body composition of brown marbled grouper Epinephelus fuscoguttatus juvenile. Jurnal Ilmu dan Teknologi Kelautan Tropis 2: 1-9. 